\title{
Human Resource Variables and Work-Related Stress in the Nigerian Banking Industry
}

\author{
Clement Adewole, Ph.D., Jessica Eboh, Victor Odumu \\ Department of Banking and Finance, University of Jos, Nigeria
}

\begin{abstract}
The Nigerian banking sector has been characterized by uncertainties which further aggravated the insecurity of jobs in the sector, resulting into work-related stress. Human Resources have been identified by many authorities as the most important asset of any organization. This is because they are the users of the rest of the resources in the organization. This work assessed the Effect of human resource variables and work-related stress in Nigerian banking industry. Data was collected using questionnaire administered to 1024 employees from the selected banks. The Spearman Rank correlation coefficient was used to test the relationship between the variables under review. Findings revealed a positive and significant relationship between performance appraisal, training and development, career management and work-related stress. Based on the findings, it is concluded that human resource variables have significant influence on work related stress in Nigerian banking industry. To this effect, the study recommended that Bank Management should provide balance scorecard approach to employees' performance, thus promoting employees when due; Continue to train employees in groups and through computer-based learning in order to stay at the forefront of one's profession and Bank Management should continue to hire employees who are suited, new competencies and skilful for the job.
\end{abstract}

Keywords: Human, Resource, Variables, Work, Stress

\section{BACKGROUND OF THE STUDY}

$\mathrm{T}$ he banking industry in Nigeria has undergone significant changes over time through ownership and operations. These changes have created several challenges in the banking industry which are identified as deregulation of financial sector, globalization, acceptable requirement that is recognized internationally etc. During the period of Soludo, the banking industry was so feeble that it presents enormous bottle necks. It acknowledged some specific bank challenges like those having weak structures, operation and low assets (Soludo, 2004). However, the Banking sector strived to transform their services from traditional to technological base by creating new services, new processes and product in order to keep a strong competitive advantage over other competitors. One of the methods for banks to improve is having effective HRM practices. HRM has moved from transactional roles, traditional personnel and administrative that are increasingly outsourced. HRM presently postulates the addition of value in an organizational strategic utilization of workforce and their program as it affects banks in a measurable way. The human resource is, of all resources appointed to man, the most beneficial, the most flexible and the most resourceful. In investigating the relationship between and work-related stress, it is imperative to put into consideration maximum individual development, desirable working relationships between employers and employees, employees and employees, and to affect the moulding of human resources as compared with physical resources.

Human Resources variables are activities of Human Resource Management with special emphasis on training and development, performance appraisal and career management. It is concerned with the framework for the expansion of human capital within an organization. In simple parlance, the aim of HRM is to enhancing the skills of employee, increasing their level of commitment which leads to increase the organization performance, output and efficiency. Banks and indeed many organizations today are increasingly recognizing the importance of developing their human resources. (Cross, 2018) are of the view that human resources management is a process for staffing the organization and sustaining high employee performance. Human resources management is the practices, systems and procedures implemented to attract, acquire, develop and manage human resources to achieve the goals and objectives of an organization. Awolusi, Onikoyi \& Akamo (2015), with few studies on work related stress in the context of Nigerian banking industry (Onwuzuligbo, 2015; Sharmilee, Abdul and Zubair, 2017); Fonkeng (2018) Awadh, Gichinga \& Anwar, 2015; Whitfield \& Cachia 2018). This has necessitated the need to investigate human resource variables and work-related stress in Nigerian banking industry.

Stress is experienced by people at work sometimes due to the conflict they feel between their independence and commitment to the organization, organization pressures for conformity, day to day demands of the workplace and various forms of role conflicts. According to Akrani (2011) stress is a general term applied to various psychologic (mental) and physiologic (bodily) pressures experienced or felt by people throughout their lives. Stress is a physical, chemical, or emotional factor that causes bodily or mental tension and may be a factor in disease causation.

The Nigerian Banking Sector witnessed shocks and distress in the recent past as a result of the economic meltdown in the western hemisphere. The meltdown and the consequent restructuring in the banking sector have significantly affected human resource management and work-related stress in the sector. Indeed, the sector has been characterized by reduction in the number of banks and uncertainties, which further aggravated the security of jobs in the sector (CBN Financial 
Stability Report, 2010). This espoused situation has resulted to work related stress.

Today, work related stress has become a major issue of increasing concern to employees and banks in Nigeria. Thus, becoming a part of life for employees, as life today has become so complex at home as well as outside that it is impossible to avoid stress. Without question, work related stress in Nigerian banking industry as a whole is linked to improper working condition for delivering duties, poor career management for flow of talent it needs and poor performance appraisal for evaluation. Overtime, long absence from family, fear of job insecurity and difficult customers were the major causes of work-related stress in the Nigerian banking industry. In fact, it is believed that excessive stress poses a hindrance to a smooth function and introduces friction lapse, inefficiency and other unpleasant variable in the operational activities of banks. Therefore, it is against this background that this study investigates the effect of human resource variables on work related stress in Nigerian banking industry while adopting performance appraisal, career management and training and development as specific human resource variables in addressing the problem of work- related stress in Nigerian banking industry.

In Ajayi (2018) on effects of Stress on Employee Performance and Job Satisfaction, it was established that job stress is considered rising and has become a challenge for the employer; high level stress results in low productivity, increased absenteeism and collection to other employee problems like alcoholism, drug abuse, hypertension and a host of cardiovascular problems. Similarly, Harry (2020) examined the relationship between stress management and employee performance and concluded that stress management bears a positive and significant influence on employee performance.

\subsection{Objectives of The Study}

The general aim of this research is to assess human resource variables and work-related stress in Nigerian banking industry. Specific objectives of this study are as follows:

A. To evaluate thoroughly the effect of performance appraisal on work related stress in the Nigerian banking industry.

B. To determine the influence of training and development on work related stress in the Nigerian banking industry.

C. To determine career management and how it affects work related stress in the Nigerian banking industry.

\subsection{Research Hypotheses}

1. Ho: Performance appraisal has no significant relationship with work related stress in the Nigerian banking industry.

2. $\mathrm{Ho}_{2}$ : Career management has no significant relationship with work related stress in the Nigerian banking industry.
3. Ho $\mathbf{H}_{3}$ : Training and development has no significant relationship with work related stress in the Nigerian banking industry.

\subsection{Significance Of The Study}

This study will be of great assistance to students and researchers who will want to further add to the existing literature on human resource variables and work-related stress in Nigerian banking industry. The research will help add to the ever-growing number of policies, measures and regulations to be implemented by policy holders. The study provides useful information to policy makers and regulators such as the CBN and government to Formulate and enhance policies and programs that will actively address problem work related stress in the Nigerian banking industry. Central Bank and financial institutions can adopt the result of the findings for smooth operations. The study will also benefit management and shareholders of banks to gain insight on human resources and work-related stress which is a field whose benefits outweighs its costs. It will help organization as they recruit and manage personnel, and particularly in a volatile economy like Nigeria, for sustenance and success of these business today.

\section{REVIEW OF RELATED LITERATURE}

\subsection{Conceptual Review}

\subsubsection{Human Resource Variables}

Human Resource Management (HRM) is a relatively new approach to managing people in any organization. People are considered the key resource in this approach. It is concerned with the people dimension in management of an organization. Since an organization is a body of people, their acquisition, development of skills, motivation for higher levels of attainments, as well as ensuring maintenance of their level of commitment are all significant activities. Human resource management is that part of the management process that specializes in the management of people in work organizations.

It emphasizes that employees are critical to achieving sustainable competitive advantage, that human resources practices need to be incorporated with the corporate strategy and that human resource specialists help organizational controllers to meet both efficiency and equity objectives (Bibi, Lanrong, Haseeb, \& Ahmad, 2012). Vanhala \& Ahteela (2011) opined that human resource management is planning and controlling activities of an organization to build and maintain the relation between employees and the organization in order to meet both business objectives and employee expectations.

\subsubsection{Performance Appraisal}

Performance appraisal is an exercise usually don at least once in the financial year of a bank. The banks set performance measures or targets which are usually aligned with budgets in the banks. In performance appraisals, actual performances are 
compared with budgets or set targets. In this performance appraisal, scores are assigned to employees based on the job performed as defined by the organization for evaluation process. Performance appraisal is the judgment of an employee's performance in a job based on certain considerations apart from productivity alone. This is also process by which a manager or consultant examines and evaluates an employee's work behaviour by comparing it with pre-set standards. Armstrong (1979) described appraisal as the process of reviewing performance and progress in a job and assessing the possibility-of-promotion. According to Cole (2002), there are two main categories of appraisal namely: Informal appraisal is the continuing assessment of an individual's performance by the superior while working. This kind of assessment is shaped by intuitive feelings not factual evidence of result. It is a by-product of the daily relationship between manager and subordinate. Formal appraisal is altogether more rational and orderly than informal appraisal

\subsubsection{Career Management}

Micheal Armstrong (2009), it deals with providing opportunities for people or individuals to develop their careers and abilities with the aim of ensuring that the firm or organization have the flow of talent it needs and to satisfy their own aspirations. It deals with bringing firm needs and the individual needs together. Career management ensures others know about you and your value, although career management is one of the five phases of career development planning. Career management is the blend of active management choice and structured planning of professional career. Employee will be encouraged to develop new product ideas without stress or under duress. Career management develop the skills and competency of the employees to deliver task assign to them to achieve the goal of the organization which pave way for the employees to also develop new process of achieving the task assign to them without stress. Career management of employee in the banking industry address the problem of work-related stress such that it will aid the bank to have a routine procedure in place design and produce product or creative services and how to get this product to end users.

\subsubsection{Training and Development}

According to Gerald Cole (2004), it deals with the preparation for a specific skills or occupation which is narrow in conception than development or education. It deals with job oriented rather than career oriented, it is also aim at employee potential than immediate skill and employees are seen as adaptable resources. Atakpa (2011), define training as a systematic development of the knowledge, skills and aptitudes vital for an individual to perform well on a job. When workers are trained, they work becomes less stressful. According to Robert (2006) continual training and reinforcement develops a work force that is competent, consistent, competitive, effective and efficient, beginning on the first day of work, providing the individual with the necessary skills to perform their job is important. According to Fredrick (2010) before the first day, it is important the interview and hiring process expose new hires to an explanation of the company, so individuals know whether the job is their best choice. Networking and strategizing within the company provide ongoing performance management and helps build relationships among co-workers (Gareth,2008).

\subsubsection{Work Related Stress in Nigerian Banking Industry}

Work related stress is correlated with a person's fear or failure. Qadoos et al (2015), opine that stress can manifest itself in both a positive and a negative way. Stress is said to be positive when a situation offers an opportunity for one to gain something, eustress is the term used to describe positive stress. It is negative when stress is associated with heart disease, alcoholism and a host of other social, physical, organizational and emotional problems, distress is the term used to describe negative stress. Eustress can be stimulating that enhances work performance and positively to encourage workers to make efforts. Distress results in negative effects over workers health and performance.

Some potential causes of work-related stress are; overwork, lack of clear instructions, unrealistic deadlines, lack of decision-making, job insecurity, isolated working conditions, surveillance, and inadequate child-care arrangements. Although sexual harassment and discrimination are often excluded from lists of traditional job stressors, they must be included in any comprehensive analysis of the causes of workplace stress. Sexual harassment is a stressor for women in the workplace; and discrimination is a stronger predictor of health outcomes, including mental ill-health, for ethnic minorities than traditional job strong the other hand, Onwuzuluigbo (2015) maintains that work stress is common to Nigerians appointed to high offices.

\subsection{Theoretical Review}

\subsubsection{Erg Theory}

This study is based on the ERG theory by Clayton Alderfer which is similar to Maslow's hierarchy of needs. However, ERG theory has only three categories namely: existence needs (similar to the Maslow's basic needs), relatedness needs (pertaining to satisfactorily relating to others) and growth needs (referring to self-development, creativity, growth and competence). Thus, ERG refers to those three categories of existence, relatedness and growth. For instance, one may go to work to make a living (existence needs satisfaction) and another may be motivated by good relations with co-workers (Alderfer, 1972).

In addition, William James and Carl Lange in 1884 and in 1885 separately proposed their respective theories on the correlation of stress and emotion which can be represented thus: Event $\Rightarrow$ Arousal $\Rightarrow$ Interpretation $\Rightarrow$ Emotion. According to the theory, when an event stimulates a person (arousal), the autonomic nervous system (ANS) reacts by creating physiological manifestations such as faster heartbeat, 
more perspiration, increased muscular tension, and more. Once these physical events occur, the brain will interpret these reactions. The result of the brains interpretation is an emotion which is likened to the - fight-or-flight $\|$ reaction, in which the bodily sensations prepare a person to run away from the situation or face it squarely.

This theory can be related to the concept of common sense which tells us that when a person encounters a dangerous wild animal, he tends to feel afraid and then he runs. According to Lange 's theory, seeing a dangerous wild animal causes the autonomic nervous system to stimulate the muscles to get tensed and the heart to beat faster. After such bodily changes, that is the time that emotion of fear emerges. (Palmer, Cooper, and Thomas 2003)

This theory is applicable to this work in the sense that a person autonomic nervous system stimulates the muscles to get tensed and the heart to beat faster when there is danger and then that is the time that emotion of fear emerges likewise, a worker performance and reactions tends to be directly affected when stress occurs as a result of physical and emotional encounters in the workplace.

\subsection{Empirical Review}

Abosede, Eze \& Sowunmi (2018) examine the effect of human resource management and banks' performance in Nigeria. Ordinary least square (OLS) was employed to estimate the model, with the aid of STATA version 14. The findings revealed that human resource management significantly affects banks' non-financial performance (Fvalue $=19.22 * 0.0000$ at $5 \%$ level of significance). The findings further revealed that Reward management and Employee performance management both have significant effect on the non-financial performance of banks in Nigeria, while Employee Resourcing does not have a significant effect on the non-financial performance of banks in Nigeria.

Bhanu and Satish (2017) studied the impact of job stress on the performance of the Bank employees. The research was descriptive in nature and used questionnaire for collection of data and a sample of 108 employees was used. The findings were that there is a significant relationship between the demographic variables like job role, gender, age, education and these impacts on occupational stress. Also, Fonkeng (2018) Effects of job-stress on employee performance in an enterprise: A microfinance institution in Cameroon. Descriptive research design was adopted and questionnaires were distributed to a sample of 100 employees. Data was presented using Microsoft excel tools and findings reveal that the employees endure excessive amount of stress which negatively affects their performance.

Ebiasuode, Onuoha \& Nwede (2017) assessed the impact of Human Resource Management (HRM) practices on organizational innovation in banks in Bayelsa State of Nigeria. The Spearman Rank order correlation coefficient was used to test the relationship between the variables under review while the partial correlation was adopted to evaluate the moderating effect of corporate culture on the relationship between HRM practices and organizational innovation. Finding revealed a positive and significant relationship between performance appraisal and all measures of organizational innovation, career management has negative relationship with product and process innovation and a positive relationship with administrative innovation, training and development is negatively related with all the measures of organizational innovation, corporate culture has no moderating effect on the relationship between HRM practices and organizational innovation.

John, Emmanuel. \& Omonona, (2020) investigated perceived occupational stress among some graduate employees in Nigeria as consequence of work experience and educational qualification. The study used the positivist explanatory crosssectional (survey) research design, and a structured and validated questionnaire to systematically sample opinions of 1,532 male and female graduate employees across the various sectors of the nation's economy. The results of the statistical analysis showed that graduate employees with more work experience expressed a significant higher level of occupational stress than their counterparts.

CahayaSanthi, Ni, Piartrini \& Putu (2020) also investigated the effect of role ambiguity on work related stress and employees' work satisfaction. The result showed that role ambiguity negatively contributed towards work satisfaction significantly. Role ambiguity positively affected towards work-related stress significantly. The implication of this result is that in order to increase job satisfaction of employees, it is necessary to pay attention to the role of ambiguity and employee work stress factors. This proved that role ambiguity and work-related stress affected the level of work-satisfaction of employee in terms of achieving company's goal.

Undie, Ukpata \& Iyortsuun (2018) assessed the impact of job stress on employee performance in the Nigerian Banking Industry. Pressure induced stress, workload induced stress and target induced stress were parameters of job stress. Three hypotheses were tested in this study: pressure induced stress, workload induced stress and target induced stress were hypothesized as having a relationship with employee performance in the Nigerian Banking Industry. Results from the regression analysis showed that pressure induced stress, workload induced stress and target induced stress are related to employee performance in the Nigerian banking industry. It was recommended that organizations should redesign jobs to reduce workload, set realistic targets that can be achieved and improve the quality of services to reduce pressure on employees

Cross (2018) investigated the impact of human resources management in Nigerian Commercial Banks in Abuja. The data for this study were purposely collected through the secondary sources and analysed using content analysis approach. The study also revealed that target setting and 
corporate value ethics are adequate and employees have job satisfaction. The observations from the study necessitated certain recommendation which required total overhaul of the role of the Human Resources department aimed at improving human resource management in the organization

Julius, Benneth \& Motunrayo (2018) examined the effect of human resource management (measured by: Reward management, Employee performance management and Employee resourcing) on non-financial performance of banks in Nigeria (measured by: market share, employees' satisfaction, efficiency, productivity and service quality). The study employed survey research design, by administering structured questionnaire. The findings further revealed that reward management and employee performance management both have significant effect on the non-financial performance of banks in Nigeria, while employee resourcing does not have a significant effect on the non-financial performance of banks in Nigeria. Also, Abosede, Eze \& Sowunmi (2018) examined the effect of human resource management on banks' performance in Nigeria. The findings revealed that human resource management significantly affects banks' nonfinancial performance.

Bhanu and Satish (2017) studied the impact of job stress on the performance of the Bank employees. The research was descriptive in nature and used questionnaire for collection of data and a sample of 108 employees was used. The findings were that there is a significant relationship between the demographic variables like job role, gender, age, education and these impacts on occupational stress. Also, Fonkeng (2018) studied effects of job-stress on employee performance and findings revealed that employees endure excessive amount of stress which negatively affects their performance.

Ebiasuode, Onuoha \& Nwede (2017) assessed the impact of Human Resource Management (HRM) practices on organizational innovation in banks and found a positive and significant relationship between performance appraisal and all measures of organizational innovation; career management had negative relationship with product and process innovation and a positive relationship with administrative innovation; training and development negatively related with all the measures of organizational innovation; corporate culture had no moderating effect on the relationship between HRM practices and organizational innovation.

\section{METHODOLOGY}

The study focused on comprehending and predicting human resource variables and as such, a positivist approach was adopted for the study. The population of the study comprised of all employees in the 24 banks in Nigeria as at study period in October 2021. The sampling frame comprised of banks in Plateau state. From this sampling frame, a non-probability judgement sample of ten (10) banks, Access, Zenith, FCMB, Union, Polaris, fidelity, Jaiz, UBA, First and GTB in Plateau State, was selected. The selection was due to their close geographic proximity, which reduces cost and time and made the research more manageable. A convenient sample of 1024 employees were drawn from the entire population. Questionnaires were administered to ten (10) selected banks. The source of data for this research was primary. Primary data were collected through the use of questionnaire distributed directly to the respondents by the researcher. Items of the questionnaire were subjected to face validity assessment to ascertain whether or not the items were related to the research problem under investigation so that the research findings could be reliable.

To ascertain the validity of the instrument, the researcher subjected the questionnaire to content validity by giving it to experts in the field of management especially the supervisors to validate.

The researcher analysed his data obtained from the questionnaire administered to employees of the various branches of the bank under study.

Table 7: Descriptive Statistics Per Factor

\begin{tabular}{|c|c|c|c|c|}
\hline \multicolumn{5}{|c|}{ Descriptives } \\
\hline & & & Statistic & $\begin{array}{c}\text { Std. } \\
\text { Error }\end{array}$ \\
\hline \multirow{8}{*}{ Performance_Appraisal } & \multicolumn{2}{|c|}{ Mean } & 3.7617 & .03487 \\
\hline & \multirow{2}{*}{$\begin{array}{c}95 \% \\
\text { Confidence } \\
\text { Interval for } \\
\text { Mean } \\
\end{array}$} & $\begin{array}{l}\text { Lower } \\
\text { Bound }\end{array}$ & 3.6933 & \\
\hline & & $\begin{array}{l}\text { Upper } \\
\text { Bound } \\
\end{array}$ & 3.8301 & \\
\hline & \multicolumn{2}{|c|}{ Std. Deviation } & 1.11589 & \\
\hline & \multicolumn{2}{|c|}{ Minimum } & 1.00 & \\
\hline & \multicolumn{2}{|c|}{ Maximum } & 5.00 & \\
\hline & \multicolumn{2}{|c|}{ Skewness } & -.776 & .076 \\
\hline & \multicolumn{2}{|c|}{ Kurtosis } & -.254 & .153 \\
\hline \multirow{8}{*}{ Career_Management } & \multicolumn{2}{|c|}{ Mean } & 3.5967 & .03940 \\
\hline & $\begin{array}{c}95 \% \\
\text { Confidence }\end{array}$ & $\begin{array}{l}\text { Lower } \\
\text { Bound }\end{array}$ & 3.5194 & \\
\hline & $\begin{array}{c}\text { Interval for } \\
\text { Mean }\end{array}$ & $\begin{array}{l}\text { Upper } \\
\text { Bound }\end{array}$ & 3.6740 & \\
\hline & \multicolumn{2}{|c|}{ Std. Deviation } & 1.26090 & \\
\hline & \multicolumn{2}{|c|}{ Minimum } & 1.00 & \\
\hline & \multicolumn{2}{|c|}{ Maximum } & 5.00 & \\
\hline & \multicolumn{2}{|c|}{ Skewness } & -.767 & .076 \\
\hline & \multicolumn{2}{|c|}{ Kurtosis } & -.582 & .153 \\
\hline \multirow[t]{3}{*}{ Training_Development } & \multicolumn{2}{|c|}{ Mean } & 4.0248 & .03136 \\
\hline & $\begin{array}{c}95 \% \\
\text { Confidence }\end{array}$ & $\begin{array}{l}\text { Lower } \\
\text { Bound }\end{array}$ & 3.9633 & \\
\hline & $\begin{array}{c}\text { Interval for } \\
\text { Mean }\end{array}$ & $\begin{array}{l}\text { Upper } \\
\text { Bound }\end{array}$ & 4.0863 & \\
\hline \multirow{5}{*}{ Work_Stress } & \multicolumn{2}{|c|}{ Std. Deviation } & .99571 & \\
\hline & \multicolumn{2}{|c|}{ Minimum } & 1.00 & \\
\hline & \multicolumn{2}{|c|}{ Maximum } & 5.00 & \\
\hline & \multicolumn{2}{|c|}{ Skewness } & -1.271 & .077 \\
\hline & \multicolumn{2}{|c|}{ Kurtosis } & 1.545 & .154 \\
\hline
\end{tabular}




\begin{tabular}{|c|c|c|c|c|}
\hline \multirow{4}{*}{} & \multicolumn{2}{|c|}{ Mean } & 3.1602 & .04159 \\
\cline { 2 - 5 } $\begin{array}{c}\text { 95\% } \\
\text { Confidence } \\
\text { Interval for } \\
\text { Mean }\end{array}$ & $\begin{array}{l}\text { Lower } \\
\text { Bound }\end{array}$ & 3.0786 & \\
\cline { 2 - 5 } & $\begin{array}{c}\text { Upper } \\
\text { Bound }\end{array}$ & 3.2418 & \\
\hline \multirow{2}{*}{ Std. Deviation } & 1.33079 & \\
\cline { 2 - 5 } & Minimum & 1.00 & \\
\cline { 2 - 5 } & Maximum & 5.00 & \\
\cline { 2 - 5 } & Skewness & -.268 & .076 \\
\hline & Kurtosis & -1.183 & .153 \\
\hline
\end{tabular}

As reflected in table 7 , the highest mean was recorded on Training Development (Mean =4.0248), followed by Performance Appraisal (Mean =3.7617) and Career Management (mean=3.5967). The lowest mean was recorded for Work Stress (Mean $=3.1602$ ). This infers that participant trust that Training Development, Performance Appraisal, and Career Management will positively influence work related stress in Nigerian banking industry. Furthermore, it is important to note that all means computed were significantly high. Thus, accentuates that Training Development, Performance Appraisal, and Career Management will positively influence work related stress in Nigerian banking industry. Similarly, table 7 shows that the highest standard deviation occurred on Work Stress (Std. Dev. =1.33079), suggesting a greater dispersion in responses to the items in this factor. Training Development recorded the lowest standard deviation $($ Std. Dev. $=0.99571)$, indicating less dispersion in responses to the items in this factor. In addition, the data set may be classified as normally distributed since table 7 indicates that none of the skewness values fall outside the -2 to 2 range, when divided by standard error. Similarly, the Kurtosis values suggest that the data set is relatively peaked than normal as the majority of the variables differed from zero.

\begin{tabular}{|c|c|c|c|c|c|c|}
\hline \multicolumn{7}{|c|}{ Table 8: Tests of Normality } \\
\hline & \multicolumn{2}{|c|}{ Kolmogorov-Smirnov } & \multicolumn{3}{|c|}{ Shapiro-Wilk } \\
\cline { 2 - 8 } & Statistic & Df & Sig. & Statistic & Df & Sig. \\
\hline PerformanceAppraisal & .281 & 1024 & .000 & .848 & 1024 & .000 \\
\hline Career Management & .318 & 1024 & .000 & .826 & 1024 & .000 \\
\hline $\begin{array}{c}\text { Training } \\
\text { Development }\end{array}$ & .292 & 1008 & .000 & .793 & 1008 & .000 \\
\hline Work Stress & .238 & 1024 & .000 & .883 & 1024 & .000 \\
\hline \multicolumn{7}{|c|}{ a. Lilliefors Significance Correction } \\
\hline
\end{tabular}

Applying statistical test (Kolmogorov-Smirnov a and ShapiroWilk) on each variable and test for hypothesis, table 8 revealed that Performance Appraisal, Career Management, Training Development and Work Stress are not normally distributed at significance level of .000. Therefore, this study applied non-parametric test to analyse hypothesis.

\subsection{Method of Data Analysis}

The researcher will analyse the relationship between the human resources variables and work-related stress in the
Nigerian banking industry using the spearman rank correlation coefficient. The data were analysed using statistical package for social science (SPSS) 25.0 and results interpreted.

\section{PRESENTATION OF DATA}

Data obtained in each section will be presented using a frequency distribution table, percentage and spearman rank correlation. This will be the adoptable tools to be used for our analysis.

Table 1: Number of questionnaires administered

\begin{tabular}{|c|c|c|c|c|c|}
\hline $\begin{array}{c}\text { Detai } \\
\text { ls }\end{array}$ & $\begin{array}{c}\text { Total no. } \\
\text { of } \\
\text { questionna } \\
\text { ires }\end{array}$ & $\begin{array}{c}\text { No. of } \\
\text { questionna } \\
\text { ires } \\
\text { returned }\end{array}$ & $\begin{array}{c}\text { Percentage } \\
\text { of } \\
\text { questionna } \\
\text { ires } \\
\text { returned }\end{array}$ & $\begin{array}{c}\text { No. of } \\
\text { unreturned } \\
\text { questionna } \\
\text { ires }\end{array}$ & $\begin{array}{c}\text { Percentage } \\
\text { of } \\
\text { unreturned } \\
\text { questionna } \\
\text { ires }\end{array}$ \\
\hline Total & 1024 & 1024 & $100 \%$ & & \\
\hline
\end{tabular}

Source: Field survey (2021).

The table 1 shows that out of the total number of 1024 questionnaires that were administered and all 1024 were filled and returned representing $100 \%$ of this total.

Table 2: Sex distribution

\begin{tabular}{|c|c|c|}
\hline Male & 600 & 58.6 \\
\hline Female & 424 & 41.4 \\
\hline Prefer not to say & 0 & 0 \\
\hline Total & 1024 & $100 \%$ \\
\hline
\end{tabular}

As depicted in Table 2, there were fewer male participants $(58.6 \%)$ than female participants $(41.4 \%)$ in the research.

Table 3: Marital status distribution

\begin{tabular}{|c|c|c|}
\hline Single & 556 & 54.3 \\
\hline Married & 356 & 34.8 \\
\hline Divorced & 100 & 9.8 \\
\hline Separated & 12 & 1.1 \\
\hline Widowed & 0 & \\
\hline Total & 1024 & $100 \%$ \\
\hline
\end{tabular}

Table 3, the marital status of participants considered indicated that 356 of the respondents were married, 556 were single, 100 were divorced, 12 were separated. This represents $54 \%$, $34.8 \%, 9.8 \%$ and $1.1 \%$ respectively.

Table 4: Age distribution

\begin{tabular}{|c|c|c|}
\hline 18_25 & 100 & 9.8 \\
\hline 26_35 & 504 & 49.2 \\
\hline 36_45 & 346 & 33.8 \\
\hline 46_55 & 50 & 4.9 \\
\hline 56 above & 24 & 2.3 \\
\hline Total & 1024 & $100 \%$ \\
\hline
\end{tabular}


The responses of participants based on age as shown in Table 4 indicated that 100 of the respondents fell within the age range of $18-25$ representing $9.8 \%, 49.2 \%$ fell within the age range of 26-35, while those who fell within the age bracket of $36-45,46-55$ and above 56 years represented $33.8 \%, 4.9 \%$ and $2.3 \%$ respectively. Those who fell within the age bracket of 26-35 are considered more in the study area than all other age range.

Table 5: Education distribution

\begin{tabular}{|c|c|c|}
\hline Primary & - & \\
\hline Secondary & 24 & 2.3 \\
\hline Diploma & 230 & 22.5 \\
\hline First degree & 450 & 43.9 \\
\hline Master's Degree & 300 & 29.3 \\
\hline Others, PHD & 20 & 2.0 \\
\hline Total & 1024 & $100 \%$ \\
\hline
\end{tabular}

Table 5, the level of education of participant indicated that, 24 were Secondary, 230 were diploma certificate holders, 450 were first degree holders, 300 were master's holders, while 20 of the participants were holders of other forms of certificates. This represents $2.3 \%, 22.5 \%, 43.9 \%, 29.3 \%$ and $2.0 \%$ respectively.

Table 6: Years of working experience distribution

\begin{tabular}{|c|c|c|}
\hline Below 5 years & 504 & 49.2 \\
\hline 5_10 & 205 & 20.0 \\
\hline 10_20 & 140 & 13.7 \\
\hline 20_30 & 100 & 9.8 \\
\hline 30 and above & 75 & 7.3 \\
\hline Total & 1024 & $100 \%$ \\
\hline
\end{tabular}

Table 6, 504, 205, 140, 100 and 75 of participants are said to have had working experience below 5years, 5-10years, 1020years, 20-30years and above 30 years. This represents $49.2 \%, 20.0 \%, 13.7 \%, 9.8 \%$ and $7.3 \%$ respectively. The low percentage of participants above 30 years indicated the low number of aged people in the banking services available.

\subsection{Data Analysis}

Test for hypothesis one: Performance appraisal has no significant relationship with work related stress in the Nigerian banking industry.

\begin{tabular}{|c|c|c|c|c|}
\hline \multicolumn{5}{|c|}{ Table 9: Correlations } \\
\hline & & & $\begin{array}{c}\text { Performance } \\
\text { Appraisal }\end{array}$ & Work_Stress \\
\hline \multirow{6}{*}{$\begin{array}{c}\text { Spearman's } \\
\text { rho }\end{array}$} & \multirow{3}{*}{$\begin{array}{c}\text { Performance } \\
\text { Appraisal }\end{array}$} & $\begin{array}{l}\text { Correlation } \\
\text { Coefficient }\end{array}$ & 1.000 & $.899^{* *}$ \\
\hline & & $\begin{array}{l}\text { Sig. (2- } \\
\text { tailed) }\end{array}$ & . & .000 \\
\hline & & $\mathrm{N}$ & 1024 & 1024 \\
\hline & \multirow{3}{*}{$\begin{array}{l}\text { Work } \\
\text { Stress }\end{array}$} & $\begin{array}{l}\text { Correlation } \\
\text { Coefficient }\end{array}$ & $.899^{* *}$ & 1.000 \\
\hline & & $\begin{array}{l}\text { Sig. (2- } \\
\text { tailed) }\end{array}$ & .000 & . \\
\hline & & $\mathrm{N}$ & 1024 & 1024 \\
\hline
\end{tabular}

The table 9 above shows the coefficients between Performance appraisal and work-related stress in the Nigerian banking industry are 1.000 and .899 . The correlation between Performance appraisal and work-related stress in the Nigerian banking industry is 0.000 . This indicate that Performance appraisal and work-related stress in the Nigerian banking industry have a positive relationship. The relationship is significant at $5 \%$ level of significance since p-value $0.000<0.05$.

Test for Hypothesis two: Career Management has no significant relationship with work related stress in the Nigerian banking industry.

\begin{tabular}{|c|c|c|c|c|}
\hline \multicolumn{5}{|c|}{ Table 10: Correlations } \\
\hline & & & $\begin{array}{c}\text { Career_Manage } \\
\text { ment }\end{array}$ & $\begin{array}{c}\text { Work_Str } \\
\text { ess }\end{array}$ \\
\hline \multirow{6}{*}{$\begin{array}{l}\text { Spearma } \\
\text { n's rho }\end{array}$} & \multirow{3}{*}{$\begin{array}{c}\text { Career_Manage } \\
\text { ment }\end{array}$} & $\begin{array}{l}\text { Correlat } \\
\text { ion } \\
\text { Coeffici } \\
\text { ent }\end{array}$ & 1.000 & $.901^{* *}$ \\
\hline & & $\begin{array}{l}\text { Sig. (2- } \\
\text { tailed) }\end{array}$ & . & . 000 \\
\hline & & $\mathrm{N}$ & 1024 & 1024 \\
\hline & \multirow{3}{*}{ Work_Stress } & $\begin{array}{c}\text { Correlat } \\
\text { ion } \\
\text { Coeffici } \\
\text { ent } \\
\end{array}$ & $.901^{* *}$ & 1.000 \\
\hline & & $\begin{array}{l}\text { Sig. (2- } \\
\text { tailed) }\end{array}$ & .000 & . \\
\hline & & $\mathrm{N}$ & 1024 & 1024 \\
\hline
\end{tabular}

The table 10 above shows the coefficients between Career Management and work-related stress are 1.000 and .901. The correlation Career Management and work-related stress is 0.000. This indicate that Career Management and workrelated stress in the Nigerian banking industry have a positive relationship. The relationship is significant at $5 \%$ level of significance since p-value $0.000<0.05$.

Test for hypothesis three: Training and development has no significant relationship with work related stress in the Nigerian banking industry.

\begin{tabular}{|c|c|c|c|c|}
\hline \multicolumn{5}{|c|}{ Table 11: Correlations } \\
\hline & & & $\begin{array}{c}\text { Training_Develo } \\
\text { pment }\end{array}$ & $\begin{array}{c}\text { Work_St } \\
\text { ress }\end{array}$ \\
\hline \multirow{6}{*}{$\begin{array}{l}\text { Spearm } \\
\text { an's rho }\end{array}$} & \multirow{3}{*}{$\begin{array}{c}\text { Training_Develo } \\
\text { pment }\end{array}$} & $\begin{array}{l}\text { Correlat } \\
\text { ion } \\
\text { Coeffici } \\
\text { ent }\end{array}$ & 1.000 & $.858^{* *}$ \\
\hline & & $\begin{array}{l}\text { Sig. (2- } \\
\text { tailed) }\end{array}$ & . & .000 \\
\hline & & $\mathrm{N}$ & 1008 & 1008 \\
\hline & \multirow[t]{3}{*}{ Work_Stress } & $\begin{array}{l}\text { Correlat } \\
\text { ion } \\
\text { Coeffici } \\
\text { ent }\end{array}$ & $.858^{* * *}$ & 1.000 \\
\hline & & $\begin{array}{l}\text { Sig. (2- } \\
\text { tailed) }\end{array}$ & .000 & . \\
\hline & & $\mathrm{N}$ & 1008 & 1024 \\
\hline
\end{tabular}


The table 11 above shows the coefficients between Training and development and Work Stress are 1.000 and .858. The correlation between Training and development and Work Stress is 0.000 . This indicate that Training and development and work-related stress in the Nigerian banking industry have a positive relationship. The relationship is significant at $5 \%$ level of significance since p-value $0.000<0.05$.

\subsection{Discussion Of Findings}

The primary objective of this study was to assess the effect of human resource variables and work-related stress in Nigerian banking industry. The first objective of this study is to evaluate thoroughly the effect of performance appraisal on work related stress in the Nigerian banking industry. The findings from the test of hypothesis revealed that there is a positive relationship between performance appraisal and work-related stress in the Nigerian banking industry given the probability value of $0.000<0.05$.

The second objective of this study is to determine the influence of training and development on work related stress in the Nigerian banking industry. The findings from the test of hypothesis revealed that there is a positive relationship between training and development and work-related stress in the Nigerian banking industry given the probability value of $0.000<0.05$.

The third objective of this study is to determine career management and how it affects work related stress in the Nigerian banking industry. The findings from the test of hypothesis revealed that there is a positive relationship between career management and work-related stress in the Nigerian banking industry given the probability value of $0.000<0.05$.

\section{CONCLUSION}

The study examined the Effect of human resource variables (performance appraisal, training and development and career management) on work related stress in Nigerian banking industry The study employed survey research method, through the administration of structured questionnaire to the targeted respondents. The findings revealed that There is a positive significant relationship between performance appraisal and work-related stress in the Nigerian banking industry. This indicates that employees perceive that performance appraisal will enhance work related stress in the Nigerian banking industry. There is a positive significant relationship between training and development and work-related stress in the Nigerian banking industry. This indicates that employees perceive that training and development will enhance work related stress in the Nigerian banking industry. There is a positive significant relationship between career management and work-related stress in the Nigerian banking industry. This indicates that employees perceive that career management will enhance work related stress in the Nigerian banking industry. The author conclude that banks need to apply these tested variables: performance appraisal, training and development and career management in their strategies in order to address issues of work-related stress which in turn will increase turnover rate and help achieve organizational goals.

\section{RECOMMENDATIONS}

Based on the analysis of the research and subsequent findings, the researcher wishes to state that worker's performance in the banking industry cannot be effective and efficient when stressed up. As a result of this, the following recommendations are articulated.

1. Bank Management should provide balance scorecard approach to employees' performance, thus promoting employees when due.

2. Bank Management should continue to train employees in groups and through computer-based learning in order to stay at the forefront of one's profession.

3. Bank Management should continue to hire employees who are suited, new competencies and skilful for the Job.

\section{REFERENCES}

[1] Abosede, J., Eze, B., \& Sowunmi, M. (2018). Human resource management and banks' performance in Nigeria. Izvestiya Journal of Varna University of Economics. 62 (2). p. 117-130.

[2] Adebola, S. A, Akpa, V. O, \& Ilori, B. O. (2017). Human resource management practices and productivity- A case of selected multinational corporations in Nigeria, International Journal of Business and Management Invention, 6(5), p.41-47.

[3] Adetayo, J.O, Ajani.J.O. \& Olabisi.O. (2014). An overview of the effects of job stress on employee's performance in Nigeria tertiary hospitals. Research Journal of Management Science. 60 (4). p. 139-153.

[4] Akrani, G. (2011). What is stress: meaning, definition. Retrieved from http://kalyancity.blogspot.com.

[5] Angelo, S. D. \& Robert, D. P. (2006). Management and Organization Review 2(2) 253-277, 1740-8776.

[6] Ajayi, S. (2018). Effect of stress on employee performance and job satisfaction: A case study of Nigerian banking industry. Retrieved from https://ssrn.com.

[7] Ali.W. U, Raheem.A. R, Nawaz.A \& Imamuddin, K. (2014). Impact of stress on job performance. Research Journal of Management Science. 3(7) p. 14-17.

[8] Amin, A., Malik, Z. K. \& Shaheen, F. (2012). Human capital investment: Its impact on the economic growth of Country (A case of Pakistan: 2000 to 2010). PUTAJ Humanities \& Social Sciences. 19, p.151-160.

[9] Awadh, I.M., Gichinga L. \& Anwar, H.A. (2015). Effects of workplace stress on employee performance in the county governments in Kenya: A case study of Kilifi county government. International Journal of Scientific and Research Publications, $5(10)$.

[10] Awolusi, O. D, Onikoyi, I. A, \& Akamo, T.O. (2015). Human resource management and business performance: A study of Nigerian banks in Ado Ekiti metropolis. International Journal of Management Science. 2(3), pp. 52-60.

[11] Bature N.U, Aminu, A. \& Ozigbo, N. (2013). Effects of work stress on employees' performance in United Bank of Africa Plc, Garki branch, Abuja. European Journal of Scientific Research.45(2) p. 260.

[12] Bewell, H., Yakubu, I., Owotunse, D. \& Ojih, E. E. (2014). WorkInduced stress and its influence on organizational effectiveness and productivity among Nigerian workers. International Multidisciplinary Journal, Ethiopia 8 (1), p.112-125. 
[13] Bhanu, P. \& Satish, S. (2017). Impact of job stress on the performance of the Bank employees (a case study of PNB Banks of Kangra district Himachal Pradesh). International Journal of Science, Environment and Technology, 6(3).

[14] Bibi, A., Lanrong, Y., Haseeb, M., \& Ahmad, I. (2012). The effect of human resource management practices on employees' job satisfaction in the universities of Pakistan. Business Management Dynamics, 1(12), 1- 14.

[15] Bontis, N., \& Serenko, A. (2009). A causal model of human capital antecedents and consequents in the financial services industry. Journal of Intellectual Capital, 10(1), 5369.

[16] CahayaSanthi, N., Putu, M. P. \& Putu, S. (2020). The Effect of Role ambiguity on Work Related Stress and Employees' Work Satisfaction, American Journal of Humanities and Social Sciences Research (AJHSSR), Volume-4, Issue-6, pp-99-10

[17] CBN Financial Stability Report (Jan 2009 - June 2010) http://www.cenbank.org/out/2010/publications/bsd/financial\%20st abilit y\%20final\%20to\%20printer\%20-\%2015102010.pdf

[18] Chovwen, C. (2013). Occupational stress among bank employees in South East, Nigeria. Research Journal of Management and Business Studies. 2(2). p. 114-119.

[19] Chukwuemeka, S. O., Nwakoby, P. \& Onwuka, E. (2019). Work stress and staff performance in selected banks in Anambra State. International Journal of Management and Entrepreneurship (IJME). 1(1).

[20] Cross, O. D. (2018). Human resource management and its effects on the performance of Nigerian commercial banks. International Journal of Managerial Studies and Research (IJMSR).6(9). p 3843.

[21] Ebiasuode. A, Onuoha, B. C \& Nwede I.G.N. (2017). Human resource management practices and organisational innovation in banks in Bayelsa State, International Journal of Advanced Academic Research |Social \& Management Sciences. 3(8).

[22] Enekwe, C.I., Agu, C.I. \& Eziedo, K.N. (2014). Stress management techniques in banking sectors in Nigeria.Jornl of Bus and Mgt. 16(7). 33-38.

[23] Fonkeng C. (2018). Effects of job-stress on employee performance in an enterprise: A microfinance institution in Cameroon. Yaoundé: Centria University of Applied Sciences.

[24] Fredrick, P. (2010). Employees' turnover repercussions. Journal of management. 6(2).

[25] Gareth, J. (2008). Human Resources Management. Ninth Edition. Sultan Chand \& Sons.

[26] Goswami T.G. (2015). Introduction: job stress and its effect on employee performance in banking sector. Indian journal of commerce \& management studies. 2(51)

[27] Harry, J. (2020). Stress management and employee performance. European Journal of Human Resource Management Studies, (5)3.

[28] John K. A, Emmanuel E. N. \& Omonona, S. (2020). Occupational stress among some Nigerian graduate employees: The impact of work experience and education, Cogent Psychology, 7:1.

[29] Julius A., Benneth E. \& Motunrayo S. (2018). Human resource management and banks' performance in Nigeria. Izvestiya Journal of Varna University of Economics, s. 62 (2). p. 117-130.

[30] Khera, S. (2010). Human resource practices and their impact on employee productivity: A perceptual analysis of private, public and foreign bank employees in India. DSM Business Review, 2(1), $65-86$.

[31] Laursen, K. \& N. J. Foss, (2003). New human resource management practices, complementarities and the impact on innovation performance, Cambridge Journal of Economics, 27 (2) 243-263.

[32] Mai, N.K. \& Yen, V.H. (2016). The effects of job stress on employee job performance - A case study at Dong Xuyen industrial zone, Vietnam. International Journal of Trade, Economics and Finance. 7(2)

[33] Marimuthu, M., Arokiasamy, L., \& Ismail, M. (2009). Human capital development and its impact on firm performance: Evidence from developmental economics. The Journal of International Social Research, 2(8), 265-272.
[34] Michael, A. (2009). Handbook of human resource management practice. 11th edition, London.

[35] Oforegbunam, E. T., \& Okorafor, G. T. (2010). Effects of human capital development on the performance of small \& medium scaled enterprises in the southeastern region of Nigeria. Journal of Sustainable Development in Africa. 12(8). 49-58.

[36] Ojo, B.B, Ogunleye, A. J. \& Olatunji, S.O. (2014). Impact of job stress on the performance of Nigeria Security and Civil Defence Corps members. Research Journal on Humanities and Social Science. 4(26). 166-175.

[37] Onwuzuligbo, O. E. (2015). Effect of work stress on the staff performance in banking industry. Journal of management and financial studies. 2 (2), 35-40.

[38] Osibanjo, O. A, Kehinde, J. O. \& Abiodun, A. J. (2012). Human resource management and employee job satisfaction: evidence from the Nigerian banking industry. Journal of Economics and Business Research, No. 1, pp. 17-32.

[39] Palmer, S., Cooper, C., and Thomas, K. (2003). Revised model of organisational stress for use within stress prevention/management and wellbeing programmes- brief update. International Journal of Health Promotion and Education 41 (2), 57-58.

[40] Panagiotis, T, Panagiotis, R. \& Charalambos, P. (2013). The effect of job-related stress on employee's satisfaction: a survey in health care. Journal of Social and Behavioural Science. 73(2013). 718726.

[41] Qadoos, Z, Ayesha, A, Tayyab, H, Toqeer, I, Hafiz, I.Y. (2015). The influence of job stress on employee's performance in Pakistan. American Journal of Social Science Research. 1(4). 221-225.

[42] Robert, M. (2006). Stress in the Work Place. 1st Edition. Pearson Publishers. New Jersey.

[43] Sharmilee B.M, Abdul, B. \& Zubair, H. (2017). Impact of job stress on employee performance. International Journal of Accounting \& Business Management. Vol. 5 (No.2). November 2017.

[44] Shipton, H., D., Fay, M., West, M., Patterson \& Birdi, K. (2005). Managing people to promote innovation. Creativity and Innovative Management. 14 (2). 118-128.

[45] Soludo, C.C. (2004). Consolidating the Nigerian banking industry to meet the development challenges of the 21 st century. Being an address delivered to the special meeting of banker's committee, held on July 6 , at the CBN Headquarter, Abuja.http://www.theaebr.com/Vol6No1Spring2008Adegbaju.pdf

[46] Sowunmi, S.O., Eleyowo I.O., Salako M.A., \&Oketokun F.O. (2015). Human resource development as a correlate of performance of the banking industry in Ogun State, Nigeria. Journal of Economics and International Finance. 7(5). 112-126.

[47] Susic P. (2013). Stress management: what can you do? St. Louis Psychologists and Counselling Information and Referral. January 24, 2013. Retrieved February 5, 2013.

[48] Undie. U.P, Ukpata S.I \& Iyortsuun A. S. (2018). Job stress and employee performance in the Nigerian banking sector. International Journal of Modern Management Sciences. 7(1). 4051.

[49] Usman, B, \& Muhammad, I.R. (2010). Impact of stress on employee's job performance; a study on banking sector of Pakistan. International journal of marketing studies. 2(1).122-126.

[50] Vanhala M. \& Ahteela, R. (2011). The effect of HRM practices on impersonal organizational trust. Management Research Review. 34(8). 869-888.

[51] Whitfield, M. \& Cachia, M. (2018). How does workplace stress affect job performance: an employee 's perspective? New Vistas. Volume 3. Issue 2. Retrieved from www.uwl.ac.uk.

[52] Yodit, T. (2010). The effect of discrimination on job performance and job satisfaction. Dissertation. University of Wolverhampton.

[53] Zahid, A. C., Sareeta, T. \& Manisha, B. (2015). Impact of human capital variables on the effectiveness of the organizations, Pakistan Journal of Commerce and Social Sciences. 9 (1). 228-240. 